\title{
The Prognostic and Predictive Value of Expression of P-AKT in Patients with FIGO IIB Locally Advanced Cervical Cancer under Chemotherapy
}

\author{
Mihriban E KOCAK ${ }^{1}$, Nagehan O BARISIK ${ }^{2}$, Alpaslan MAYADAGLI ${ }^{1}$,Cengiz GEMICI ${ }^{1}$, \\ Makbule EREN ${ }^{1}$, Murat NAKI ${ }^{3}$, Naciye OZSEKER ${ }^{1}$, Atinc AKSU ${ }^{1}$ \\ ' Kartal Research and Training Hospital, Department of Radiation Oncology \\ ${ }^{2}$ Kartal Research and Training Hospital, Department of Pathology \\ ${ }^{3}$ Bagcilar Research and Training Hospital 1, Department of Obstetrics and Gynecology, Istanbul, TURKEY
}

\begin{abstract}
To evaluate the relation between expression of P-Akt and radiotherapy response, disease-free survival and overall survival in cervical cancer patients. A total of 50 patients with FIGO stage IIB locally advanced squamous cell cervical cancer treated primarily with chemoradiotherapy were included in the present study. All patients received external beam radiotherapy (EBRT; 46-50.4 Gy with 1.8-2 Gy of daily fraction, five times a week) followed by high-dose rate brachytherapy (HDR 26 Gy at point A, with 6.5 Gy per fraction a week for 4 weeks). Chemotherapy consisted of $40 \mathrm{mg} / \mathrm{m} 2$ cisplatin i.v. once a week for 5 weeks concomitant with external pelvic radiation. Paraffin-embedded, formalin-fixed primary tumor tissue was collected from each patient to identify P-Akt expression, retrospectively. The median follow up time for the study population was 30 (12-120) months. Expression of P-Akt was identified in $86 \%$ (43/50) of patients. Overall 3-years survival and disease free survival were $89.3 \%$ and $79 \%$; respectively in the study population. There was no significant association between P-Akt staining and survival $(89 \%$ vs $85.7 \%, p=0.641)$ and disease-free survival ( $80 \%$ vs $88.2 \%, p=0.498$ ). There was no relation between expression of P-Akt and treatment response, size of the tumor, lymph node status, age, local and distant failures. Univariate analysis revealed significantly reduced overall 3-years survival and disease free survival only for patients with poor treatment response $(p=0.001)$. In multivariate analysis, treatment response was found to be statistically significant parameter only for DFS ( $p=0.001$ ). In conclusion, in our study, expression of P-Akt was detected in majority of cervical cancer patients. However no correlation was observed between P-Akt staining degree and treatment response
\end{abstract}

Keywords: P-Akt expression, Cervical cancer, Chemoradiotherapy, Radiation response

\section{ÖZET}

Kemoradyoterapi Uygulanan FIGO IIB Lokal İleri Servikal Kanserli Hastalarda P-AKT Ekspresyonunun Prediktif ve Prognostik Değeri

Serviks kanserli hastalarda, P-Akt ekspresyonu ile radyoterapi cevabı, hastalıksız sağkalım ve tüm sağkalım arasındaki ilişkiyi değerlendirmek. Bu çalsşmaya, primer kemoradyoterapi ile tedavi edilen, FIGO IIB lokal ileri skuamoz hücreli serviks kanserli 50 olgu dahil edildi. Tüm hastalar eksternal radyoterapi (EBRT; 46-50.4 Gy, günlük fraksiyon 1.8-2 Gy , haftada 5 gün) ve takiben yüksek doz oranlı brakiterapi (A noktasına 26 Gy, fraksiyon dozu 6.5 Gy,haftada bir, 4 hafta boyunca) aldilar. Kemoterapi eksternal pelvik radyoterapi ile eş zamanlı haftada bir $40 \mathrm{mg} / \mathrm{m} 2$ cisplatin olarak uygulandı. Her hastanın formalinle fikse edilmiş parafin blokları toplanarak retrospektif olarak P-Akt ekspresyonuna bakıldı. Boyanma 0 dan 3'e kadar skorlandı. 
Boyanma olmaması (0), <\%50 zayıf yoğunlukta boyanma (+1), >\%50 zayıf veya orta yoğunlukta boyanma (+2) ve \%50 üzerinde güçlü yoğunlukta boyanma (+3) olarak skorlandı. İstatistiksel analiz için skor 0 ve +1 olanlar P-Akt negatif olarak, skor +2 ve +3 olanlar P-Akt pozitif olarak sınıflandırıldı. Medyan takip süresi 30 (12-120) aydı. Hastaların \%86' sında (43/50) P-Akt ekspresyonu pozitif olarak tespit edildi. 3 yıllık tüm sağkalım ve hastalıksız sağkalım sırasıyla \%89.3 ve \% 79 olarak bulundu. P-Akt boyanma durumu (pozitif boyanma / negatif boyanma) ile sağkalım (89\% ve 85.7\%, p=0.641) ve hastalıksız sağkalım (\%80 ve \% 88.2, p=0.498) arasında istatistiksel anlamlı bir ilişki saptanmadı. P-Akt ekspresyonu ile tedaviye yanıt, tümör boyutu, lenf nodu durumu, yaş, lokal nüks ve uzak metastaz gelişimi arasında anlamlı bir ilişki saptanmadı. Univariye analizde tedaviye kötü yanıt alınan hastalarda hem 3 yıllık hastalıksız sağkalım, hem de 3 yıllık tüm sağkalım daha kötü bulundu ( $p=0.001)$. Multivariye analizde ise yalnızca, tedaviye kötü yanıt hastalıksız sağkalım için anlamlı bir parametre olarak bulundu ( $p=0.001)$.

Servikal kanserli hastaların çoğunda P-Akt pozitif ekspresyonu gözlenmiştir. Ancak boyanma derecesi ile tedaviye cevap arasında bir korelasyon gözlenmemiştir.

Anahtar Kelimeler: P-Akt ekspresyonu, Servikal kanser kemoradyoterapi, Tedavi yanıtı, Sağkalım

\section{INTRODUCTION}

Cervical carcinoma has a significant place among gynecological tumors due to its prevalence and mortality rate. The standart therapy of locally advanced cervical cancer is cisplatin-based concomitant chemoradiotherapy.

For cervical cancer, as well as other cancers, in order to predict treatment outcome and resistance to therapy, besides the classical clinicopathological factors (FIGO stage, tumor size defining bulky disease as tumors larger than $4 \mathrm{~cm}$, histology, lymph node status and age whom young or older age), biological and molecular markers continue to be investigated.

EGFR and downstream pathways that have a role in carcinogenesis and when overexpressed, are shown to have a connection with therapy resistance and poor prognosis, are one of the major factors under investigation. ${ }^{1-6}$ It is shown in several studies that high levels of EGFR amplification and overexpression are present in cervical cancer..$^{7-10}$ One of the specific signal tranduction pathways, phosphatidylinositol 3-kinase (PI3K)/Akt pathway is activated by stimulation of EGFR family via certain growth factors and cytokines. ${ }^{11-13} \mathrm{Akt}$ is a protein kinase first identified in 1991 and it regulates cell survival. In case of cellular stress, Akt which gets activated by phosphorylation (P-Akt) prevents apoptosis, and powerfully stimulates survival and growth signals..$^{14}$ Activation of Akt is related with malignant transformation characterized by accelerated tumor growth, metastasis and angiogenesis. ${ }^{12}$ Besides, activation of Akt diminishes the sensitivity of tumor cells to chemotherapy and radiotherapy. ${ }^{15}$

Increased expression of P-Akt level in tumor tissue is found to be related with decreased response to radiotherapy in tumors such as head\&neck cancer, lung cancer, glioblastoma multiforme, prostate and breast cancer. ${ }^{16-22}$ There are also studies on cervical cancer which show a relationship between P-Akt expression level and disease-free survival (DFS) and radiotherapy response..$^{23-25}$ In 2005, Lee et al., observed that in 55 cervical cancer patients treated with radiotherapy, with Akt overexpression, there was a significant improvement in DFS. ${ }^{23}$ In 2006, Kim et al., in 27 cervix carcinoma patients 9 of whom showed recurrence after primary radiotherapy, unlike the study of Lee, showed that P-Akt positivity was correlated with radiation resistance and local recurrence and those patients had a worse prognosis. ${ }^{24}$ Faried et al., in 26 cervical cancer patients to whom preoperative chemotherapy was given, reported that P-Akt negative cases had a better survival and prognosis. ${ }^{25}$

In our study, in the tumor tissues of 50 FIGO IIB cervical cancer patients, we investigated the association between P-Akt expression level and response to chemoradiotherapy, DFS and overall survival (OS).

\section{PATIENTS AND METHODS}

Between 2001 and 2009, in Kartal Education\&Research Hospital Oncology Department, FIGO stage IIB locally advanced sqamous cell cervical cancer patients were concomitantly treated with chemotherapy and radiotherapy. Fifty patients among this group that reached parafin blocks were retrospectively analysed in the present study. The tumor volume was determined with Magnetic Resonance Imaging (MRI) and clinical examination. All of the 


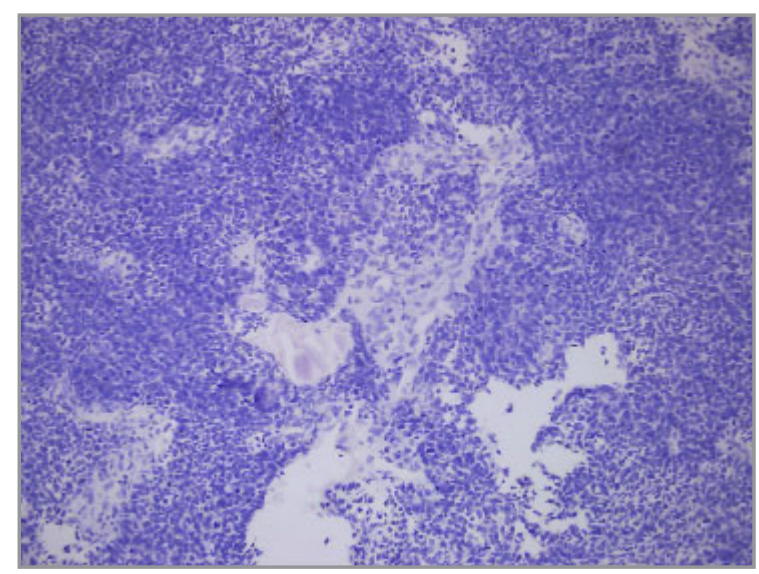

Figure 1. P-Akt expression in tumour specimens at 20X magnification. A: P-Akt negative (0)

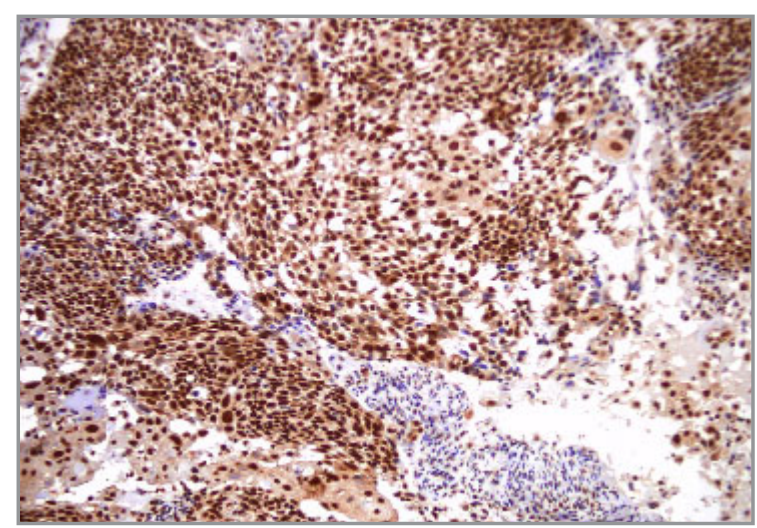

Figure 3. P-Akt expression in tumour specimens at 20X magnification. C: P-Akt positive (+)

patients received external beam radiotherapy (EBRT). The whole pelvis total dose was 46-50.4 Gy with 1.8-2 Gy of daily fraction, administered five times a week (minimum: $43 \mathrm{~Gy}$, maximum 54 Gy, median:50 Gy). Treatment fields involved gross tumor volume and regional lymph node regions ( common iliac, external iliac, internal iliac and presacral lymph nodes) . Also para-aortic region evaluated by MRI and no prophylactic irradiation to the para-aortic lymph node area was performed.

High-dose rate (HDR) brachytherapy was started 56 weeks after the initiation of the EBRT. The dose of HDR brachytherapy was 26 Gy at point A, with 6.5 Gy per fraction applied weekly for 4 weeks (minimum: 24,5 Gy, maximum: $29 \mathrm{~Gy}$, median: $26 \mathrm{~Gy}$ ) Patients who were unable to have brachytherapy $(8$ patients) were given an external beam radiotherapy

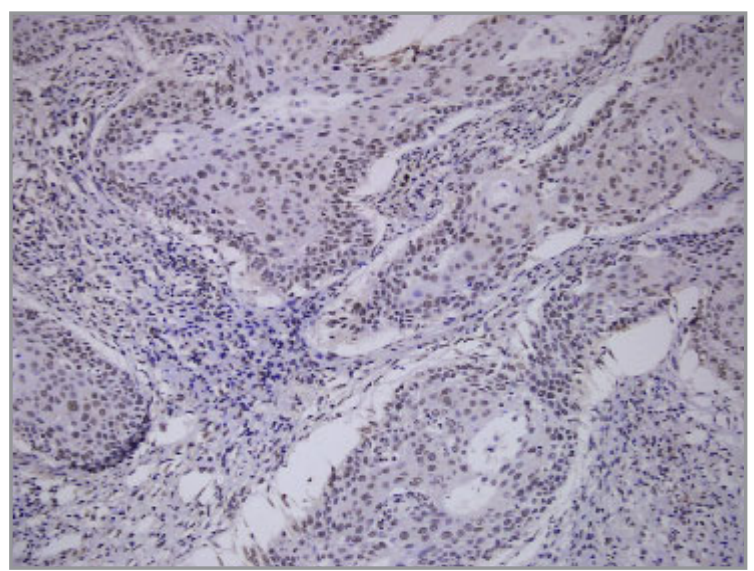

Figure 2. P-Akt expression in tumour specimens at 20X magnification. B: P-Akt poor staining (+)

boost (14-20 Gy). The boost dose was limited to the 66-70 Gy due to risk of the rectitis. Chemotherapy consisted of $40 \mathrm{mg} / \mathrm{m}^{2}$ cisplatin i.v. once a week for 5 weeks concomitant with external pelvic radiation.

Response to treatment was evaluated 1.5-2 months after chemoradiotherapy. The patients who did not have any tumor clinically and radiologically (MRI) were considered radioresponsive; if partial response or stable disease was present, patients were considered radioresistant.

\section{Immunohistochemical Staining}

Only one pathologist evaluated the all immunohistochemical staining. Firstly, $3 \mu \mathrm{m}$ paraffin sections were cut from the paraffin embedded tumor tissue and mounted on adhesive coated glass slides. They were then deparaffinized in xylene three times for 5 min and rehydrated through a series of graded alcohols and purified water All sections were blocked from nonspecific binding by endogen peroxide (Lecia; LOT 11776) for $15 \mathrm{~min}$ and then incubated with P-Akt monoclonal Mouse anti-human (Novocastra Liquid, Cod NCL-L-Akt-Phos, ready for use,United Kingdom). Post primary antibody, polimer antibody and DAB mixtures (Leica; LOT 11776) were added to the sections, respectively each for 10 minutes. After washed in water, the slides were lightly counterstained with Hematoxylin. The staining was scored on a scale from 0 to $3+$ as follows: no staining $(0),<50 \%$ with weak intensity $(1+)$, more than $50 \%$ with weak or moderate intensity $(2+)$, more than $50 \%$ with strong intensity $(3+)$ : 


\begin{tabular}{|c|c|}
\hline Patients characteristics & n (\%) \\
\hline \multicolumn{2}{|l|}{ Age } \\
\hline Median (range) & $52.5(29-77)$ \\
\hline \multicolumn{2}{|l|}{ Tumor diameter } \\
\hline$\leq 4 \mathrm{~cm}$ & $18(36)$ \\
\hline$>4 \mathrm{~cm}$ & $32(64)$ \\
\hline \multicolumn{2}{|l|}{ Response to treatment } \\
\hline Partial response & $5(10)$ \\
\hline Complete response & $45(90)$ \\
\hline \multicolumn{2}{|l|}{ Recurrence pattern } \\
\hline Local & $2(4)$ \\
\hline Distant & $6(12)$ \\
\hline Local and distant & $2(4)$ \\
\hline \multicolumn{2}{|l|}{ Current status } \\
\hline Exitus & $4(8)$ \\
\hline Disease free survival & $38(76)$ \\
\hline Survival with disease & $8(16)$ \\
\hline \multicolumn{2}{|l|}{ P-Akt staining } \\
\hline \multirow{2}{*}{$\begin{array}{ll}\text { Negative (n: 7) } & 0 \\
& +\end{array}$} & $1(2)$ \\
\hline & $6(12)$ \\
\hline \multirow[t]{2}{*}{ Positive (n: 43) } & $11(22)$ \\
\hline & $32(64)$ \\
\hline
\end{tabular}

For statistical analysis of survival curve, we classified the P-Akt expression of score 0 or 1+ as P-Akt negative, score $2+$ or $3+$ as $\mathrm{P}$-Akt positive. ${ }^{24}$

\section{Statistical Analysis}

Statistical analysis were performed using SPSS 17.0 software system. The clinicopathologic features of difference parameters were compared with Fisher's exact test. Survival curves were plotted using the Kaplan-Meier method and the log-rank test was used to assess any differences. Cox proportional hazard model was applied for evaluation of the relationship between different variables and survival. $\mathrm{P}$ values $\leq .05$ were considered to be statistically significant.

\section{RESULTS}

All the patients received external pelvic radiotherapy. In $8(16 \%)$ cases who did not become suitable for brachytherapy, subsequently, external boost dose was given. All the patients were able to receive weekly cisplatin. Patient characteristics are described in Table 1.

The median follow up for the patients was 30 (12$120)$ months. During follow-up, $46(92 \%)$ patients was still alive. The patients who did not have any tumor clinically and radiologically (MRI) were considered radioresponsive; if partial response or stable disease was present, patients were considered radioresistant.

\begin{tabular}{|c|c|c|c|c|}
\hline Characteristics & P-Akt (+) & P-Akt (-) & Total & $P$ value \\
\hline \multicolumn{5}{|l|}{ Treatment response } \\
\hline Radioresponsive & 38 & 7 & 45 & 0.454 \\
\hline Radioresistant & 5 & 0 & 5 & \\
\hline \multicolumn{5}{|l|}{ Local control } \\
\hline Local recurrence (+) & 4 & 0 & 4 & 0.536 \\
\hline Local recurrence (-) & 39 & 7 & 46 & \\
\hline \multicolumn{5}{|l|}{ Distant failure } \\
\hline Distant (+) & 6 & 5 & 11 & 0.310 \\
\hline Distant (-) & 37 & 2 & 39 & \\
\hline \multicolumn{5}{|l|}{ Age } \\
\hline$\leq 60$ & 36 & 5 & 41 & 0.370 \\
\hline$>60$ & 7 & 2 & 9 & \\
\hline \multicolumn{5}{|l|}{ Lymph node (LN) } \\
\hline Pelvic LN (+) & 7 & 0 & 7 & 0.323 \\
\hline Pelvic LN(-) & 36 & 7 & 43 & \\
\hline \multicolumn{5}{|l|}{ Tumor diameter } \\
\hline$\leq 4 \mathrm{~cm}$ & 17 & 1 & 18 & 0.197 \\
\hline$>4 \mathrm{~cm}$ & 26 & 6 & 32 & \\
\hline
\end{tabular}


According to evaluation done 2 months after treatment, complete clinical and radiological response were obtained in $45(90 \%)$ patients (radiation-responsive group). During follow-up, 2 (4\%) patients had only local and 2 (4\%) had both local progression and distant metastasis, $6(12 \%)$ had only distant metastasis. Three out of 4 patients, whom locally reccured or progressed were in the treatment resistant group. Distant metastasis were found in the lung in $1(2 \%)$ patient, in bone in $3(6 \%)$, in paraaortic lymph node in $4(8 \%)$ patients. Local recurrence/progression was seen after median 5 months (5-18 months) and distant metastasis, after median 8 months (3-14 months).

In 86\% (43/50) of the patients, P-Akt positive expression was observed. There was no significant relationship between P-Akt expression levels and response to treatment, local recurrence, distant metastasis, age, tumor diameter, lymph node status (Table 2).

For all the group, 3- year overall survival (OS) was $89.3 \%$, and DFS was $79 \%$. There wasn't any statistical significant difference between P-Akt positivity or negativity and survival $(89 \%$ vs $85.7 \%, \mathrm{p}=$ 0.641 ) and DFS ( $80 \%$ vs $88.2 \%, \mathrm{p}=0.498$ )

In univariate analysis, for patients without response to treatment, DFS and OS were obviously poor $(\mathrm{p}=0.001)$ (Table 3,4). In multivariate analysis, treatment response was found to be statistically significant parameter only for DFS ( $p=0.001)$.

\begin{tabular}{|lll|}
\hline \multicolumn{3}{|l|}{ Table 3. Univariate analysis for survival } \\
\hline Characteristics & $\mathbf{3}$ years (\%) & P -value \\
\hline $\begin{array}{l}\text { Lymph node (LN) } \\
\quad \text { Pelvic LN (+) }\end{array}$ & 66.7 & 0.549 \\
$\quad$ Pelvic LN (-) & 93 & \\
Age & & \\
$\quad \leq 60$ & 89.5 & 0.670 \\
$\quad>60$ & 88.9 & \\
Tumor diameter & & \\
$\quad>4$ cm & 90.6 & 0.744 \\
$\quad \leq 4$ cm & 75 & \\
Chemoradiotherapy response & & \\
$\quad$ Complete response & 97.8 & 0.001 \\
$\quad$ Partial/ stable & 0 & \\
P-akt & & \\
$\quad(+)$ & 79.7 & 0,857 \\
$(-)$ & 84.4 & \\
\hline
\end{tabular}

\section{DISCUSSION}

In our study we investigated the predictive and prognostic value of P-Akt expression in 50 FIGO IIB squamous cell cervical carcinoma cases who were treated with chemoradiotherapy. We did not find any statistically significant difference between P-Akt expression and OS, DFS and response to chemoradiotherapy.

P-Akt is a member of PI3K/Akt pathway which is one of the biological markers under investigation in cervical cancer with expectation to give support for treatment strategies and improve treatment outcomes. Radiation- induced EGFR signaling activates the PI3K/Akt pathway; this may result in inhibition of apoptosis and promotion of cell proliferati$\mathrm{on}^{12}$ and in turn, this may cause the failure of radiotherapy. Another issue to be investigated is the presence of PI3K/AKT in tumor tissue. In the study of Zhang et al., ${ }^{26}$ in different stages of cervical cancers, PI3K protein expression was detected in 25 out of $31(80.6 \%)$ tumor specimens and in 7 out of 15 non-neoplastic specimens (46.6\%). A significant over-expression was observed in tumor tissues compared with non-neoplastic tissue $(p<0.01)$. In the study performed by Noordhuis et al. ${ }^{27}$ in 2009, P-Akt expression was detected in only $4.1 \%$ of the 375 IB-IVA cervical cancer patients . Although the same antibody and protocol for immunostaining were used, only $4.1 \%$ expression of P-Akt was found which is low with respect to other studies reported. Therefore in that study, any

\begin{tabular}{|c|c|c|}
\hline Characteristics & 3 years $(\%)$ & $P$ value \\
\hline \multicolumn{3}{|l|}{ Lymph node (LN) } \\
\hline Pelvic LN (+) & 71.4 & 0.624 \\
\hline Pelvic LN (-) & 80.4 & \\
\hline \multicolumn{3}{|l|}{ Age } \\
\hline$\leq 60$ & 79.5 & 0.721 \\
\hline$>60$ & 76.2 & \\
\hline \multicolumn{3}{|l|}{ Tumor diameter } \\
\hline$>4 \mathrm{~cm}$ & 80.5 & 0.774 \\
\hline$\leq 4 \mathrm{~cm}$ & 76.4 & \\
\hline \multicolumn{3}{|c|}{ Chemoradiotherapy response } \\
\hline Complete response & 83.2 & 0.001 \\
\hline Partial/ stable & 0 & \\
\hline \multicolumn{3}{|l|}{ P-akt } \\
\hline$(+)$ & 88.2 & 0.498 \\
\hline$(-)$ & 80 & \\
\hline
\end{tabular}


comment on the relation between P-Akt expression and response to therapy and survival could not be made. In our study, P-Akt expression was found in $86 \%$ of the patients $(43 / 50)$. However, in our study as well as Zang's, any statistically significant correlation between PI3K and P-Akt expression and clinicopathological parameteres was not found.

In the study by Lee et al. ${ }^{23}$, P-Akt expression was related to good prognosis while Kim et al..$^{24}$ and $\mathrm{Fa}$ ried et al..$^{25}$ found that P-Akt expression was associated with poor porgnosis. In a recent systematic review including 42 trials searching 82 cell biological markers, despite evidence on the relation of EGFR and C-erbB-2 with poor chemoradiotherapy response, P-Akt did not show a relation with respon$\mathrm{se}^{28}$

Even though theoretically P-Akt expression negatively effects response to radiotherapy and treatment outcomes, in our study expected correlation was not observed. Our study P-Akt expression was found in $86 \%$ of the patients $(43 / 50)$. Due to imbalance of patients number who P-Akt expression was found and not found may be resulted with insignificant. Larger prospective studies on the prognostic and predictive role of P-Akt will be enlightening.

\section{REFERENCES}

1. Neal DE, Marsh C, Bennett MK, et al. Epidermal growth factor receptors in human bladder cancer: comparisons of invasive and superficial tumors. Lancet 1: 366-368, 1985.

2. Sainsbury JRC, Farndon JR, Needham GK, et al. Epidermal growth factor receptor as predictor of early recurrence of and death from breast cancer. Lancet 1 : 1398-1402, 1987.

3. Hendler F, Shum Siu A, Nanu L, et al. Overexpression of EGF receptors in squamous tumors is associated with poor survival. J Cell Biochem (Suppl 12A): 105 (Abstr), 1988.

4. Bauchnecht T, Kohler M, Janz I, et al. The occurrence of epidermal growth factor receptors and the characterization of EGF-like receptors and the characterization of EGF-like factors in human ovarian, endometrial, cervical and breast cancer. J Cancer Res Clin Oncol 115: 193-199, 1989.

5. Ozawa S, Ueda M, Ando N, et al. Prognostic significance of epidermal growth factor receptor in esophageal squamous cell carcinomas. Cancer 2169-2173, 1989.
6. Reese DM, Slamon DJ. HER-2/neu signal transduction in human breast and ovarian cancer. Stem Cells 15: 1-8, 1997.

7. Kim JW, Kim DK, Song CH, Lee JW. Expression of epidermal growth factor receptor in carcinoma of the cervix. Gynecol Oncol 42: 256-264,1991.

8. Kristensen GB, Holm R, Abeler VM, Trope CG. Evaluation of the prognostic significance of cathepsin D, epidermal growth factor receptor and c-erbB-2 in early cervical squamous cell carcinoma. Cancer (Phila), 78: 433-440,1996.

9. Gaffney DK, Haslam D, Tsodikov A, et al. Epidermal growth factor receptor (EGFR) and vascular endothelial growth factor (VEGF) negatively affect overall survival in carcinoma of the cervix treated with radiotherapy. Int J Radiat Oncol Biol Phys 56: 922-928, 2003.

10. Noordhuis MG, Eijsink JJ, Ten Hoor KA, et al. Expression of Epidermal Growth Factor Receptor (EGFR) and Activated EGFR Predict Poor Response to (Chemo)radiation and Survival in Cervical Cancer. Clin Cancer Res 15: 7389-7397, 2009.

11. Salomon DS, Brandt R, Ciardiello F, Normanno N. Epidermal growth factor-related peptides and their receptors in human malignancies. Crit Rev Oncol Hematol 19: 183-232, 1995.

12. Yarden. Untangling the ErbB Signalling Network. Nat Rev Mol Cell Biol 2: 127-137, 2001.

13. Blume-Jensen $P$, Hunter $T$. Oncogenic kinase signaling. Nature 411: 355-364, 2001.

14. Chang F, Lee JT, Navolanic PM, et al. Involvement of PI3K/Akt pathway in cell cycle progression, apoptosis and neoplastic transformation: A target for cancer chemotherapy. Leukemia 17: 590-603, 2003.

15. Engelman JA. Targeting PI3K signalling in cancer: opportunities, challenges and limitations. Nat Rev Cancer 9: 550-562, 2009.

16. Dent $\mathrm{P}$, Yacoub A, Contessa J, et al. Stress and radiation-induced activation of multiple intracellular signaling pathways. Radiat Res 159: 283-300, 2003.

17. Gupta AK, Cerniglia GJ, Mick R, et al. Radiation sensitization of human cancer cells in vivo by inhibiting the activity of PI3K using LY294002. Int J Radiat Oncol Biol Phys 56: 846-853, 2003.

18. Choe G, Horvath S, Cloughesy TF, et al. Analysis of the phosphatidylinositol 3'-kinase signaling pathway in glioblastoma patients in vivo. Cancer Res 63: 27422746, 2003.

19. Liao Y, Grobholz R, Abel U, et al. Increase of AKT/PKB expression correlates with Gleason pattern in human prostate cancer. Int J Cancer 107: 676-680.

20. Schmitz KJ, Otterbach F, Callies R, et al. Prognostic relevance of activated Akt kinase in node-negative breast cancer: a clinicopathological study of 99 cases. Mod Pathol 17: 15-21, 2004. 
21. Blackhall $F H$, Pintilie $M$, Michael $M$, et al. Expression and prognostic significance of kit, protein kinase B, and mitogen-activated protein kinase in patients with small cell lung cancer. Clin Cancer Res 9: 2241-2247, 2003.

22. Gupta AK, McKenna WG, Weber CN, et al. Local recurrence in head and neck cancer: relationship to radiation resistance and signal transduction. Clin Cancer Res 8: 885-892, 2002.

23. Lee CM, Shrieve DC, Zempolich KA, et al. Correlation between human epidermal growth factor receptor family (EGFR, HER2, HER3, HER4), phosphorylated Akt (P-Akt), and clinical outcomes after radiation therapy in carcinoma of the cervix. Gynecol Oncol 99: 415-421, 2005.

24. Kim TJ, Lee JW, Song SY, et al. Increased expression of PAKT is associated with radiation resistance in cervical cancer. Br J Cancer 94: 1678-1682, 2006.

25. Faried LS, Faried A, Kanuma T, et al. Predictive and prognostic role of activated mammalian target of rapamycin in cervical cancer treated with cisplatinbased neoadjuvant chemotherapy. Oncol Rep 16: 57 63, 2006.

26. Zhang XY, Zhang HY, et al. Elevated phosphatidylinositol 3-kinase activation and its clinicopathological significance in cervical cancer. Eur J Obstet Gynecol Reprod Biol 139: 237-244, 2008.

27. Noordhuis MG, Eijsink JI, Ten Hoor KA, et al. Expression of epidermal growth factor reseptor (EGFR) and activated EGFR predict poor response to (chemo)radiation and survival in cervical cancer. Clin Cancer Res 15: 7389-7397, 2009.

28. Noordhuis MG, Eijsink JJH, Roossınk F, et al. Prognostıc cell biological markers in cervical cancer patients primarly treated with (chemo)radiation: A systematic review. Int J Radiation Oncol Biol Phys 79: 325-334, 2011.

\section{Correspondence}

Dr. Mihriban Kocak

Barbaros mah. Karanfil sok.

Kentplus 2A-D4 Blok Daire: 18

Batı Ataşehir

ISTANBUL / TURKEY

Tel: (+90.532) 4153062

Fax: (+90.216) 4415162

e-mail: mihribankocak@hotmail.com 